UDC 303.09

LBC 60.561 .3

\title{
CONSTRUCTING THE IMAGE OF RUSSIA THROUGH METAPHORICAL FRAMING ${ }^{1}$
}

\author{
Inna V. Skrynnikova \\ Volgograd State University, Volgograd, Russian Federation
}

\begin{abstract}
The paper reveals the key role of metaphor as a discursive pragmatic mechanism for promoting a positive image of Russia and substantiates the effectiveness of metaphorical framing as a method of constructing the country's image, which is still controversial. The author has demonstrated the explanatory and manipulative effect of metaphorical framing in political and mass media communication. The study postulates that in framing of political events, the figurative language has both linguistic and conceptual content, and the metaphorical frame is a powerful tool for the formation of beliefs and ideologies. The author points out to the need to expand the metaphorical repertoire applied to construct the image of Russia, and possible ways to activate alternative interpretations of current socio-political events. Possible directions of metaphorical reframing of the country's image are outlined by fixing complex figurative frames in the minds of target audience and their impact on it. These may consist in rejecting the excessively militarized discourse around the country and focusing on its cultural heritage, academic achievements, willingness of and openness to enhanced international interaction. The paper concludes that the discursive construction of the affirmative Russian image within and outside the country can be achieved through employing a positively charged metaphorical national narrative, reframed to draw particular attention to the merits and gains of Russia.

Key words: image of Russia, national identity, conceptual metaphor, figurative (re)framing, narrative, speech impact, beliefs, ideology.

Citation. Skrynnikova I.V. Constructing the Image of Russia Through Metaphorical Framing. Logos et Praxis, 2021, vol. 20, no. 1, pp. 49-57. DOI: https://doi.org/10.15688/lp.jvolsu.2021.1.6
\end{abstract}

УДК 303.09

ББК 60.561 .3

\section{КОНСТРУИРОВАНИЕ ОБРАЗА РОССИИ МЕТОДОМ МЕТАФОРИЧЕСКОГО ФРЕЙМИНГА ${ }^{1}$}

\author{
Инна Валериевна Скрынникова \\ Волгоградский государственный университет, г. Волгоград, Российская Федерация
}

\begin{abstract}
Аннотация. В статье выявлена ключевая роль метафоры как дискурсивного прагматического механизма продвижения положительного образа России и обосновывается эффективность метафорического фрейминга как метода конструирования имиджа страны, который до сих пор остается спорным. Автор продемонстрировал экспланаторный и манипулятивный эффект метафорического фрейминга в политической и массмедийной коммуникации. Постулируется, что во фрейминге политических событий образный язык обладает как языковым, так и концептуальным содержанием, а метафорический фрейм является мощным инструментом формирования убеждений и идеологий. Автор указывает на необходимость расширения метафорического репертуара, применяемого для конструирования России, и возможные способы активации альтернативных трактовок существующих общественно-политических событий. Намечены возможные направления метафорического рефрейминга образа страны путем закрепления сложных образных фреймов в сознании различной целевой аудитории и их воздействия на нее. Перспективным является отказ от излишне милитаризованного дискурса вокруг страны и акцентирование внимания на культурном наследии, научных достижениях, открытости и готовности к укреплению ее международного взаимодействия. В статье делается вывод, (2) что дискурсивное конструирование позитивного образа России в стране и за ее пределами может быть
\end{abstract}


достигнуть путем эффективного рефрейминга национального метафорического нарратива с целью привлечения внимания к заслугам России и усилению ее позиций.

Ключевые слова: образ России, национальная идентичность, концептуальная метафора, образный (ре)фрейминг, нарратив, речевое воздействие, убеждения, идеология.

Цитирование. Скрынникова И. В. Конструирование образа России методом метафорического фрейминга // Logos et Praxis. - 2021. - Т. 20, № 1. - С. 49-57. - (На англ. яз.) - DOI: https://doi.org/10.15688/lp.jvolsu.2021.1.6

\section{Introduction}

The critical role of representations and images in the modern communicative space is hardly disputable across various research paradigms. They are employed to construct public and political discourses and assist in fixing and implementing the ideas of social and political institutions as well as in forming the systems of social beliefs through manipulating public consciousness. Despite Russia's recent endeavours to renew and positively reframe both the domestic and international discourse around the country, its image in the public and political space remains controversial and is still shaped by negative stereotypes. The Russian society has repeatedly demonstrated its considerable demand for constructing a positive image of Russia. It is expected not only to retain the conceptual unity but also possess a high adaptability potential along with its capability of "being set" for a particular target audience. Constructing a favourable image of Russia is also critical for reputational, marketing and image-building purposes forming the resistance of public and political discourse subjects to the stereotypes of Cold War, bloc mentality destructively affecting interstate, institutional and interpersonal trust. It would also recruit supporters of interethnic dialogue and cooperation in order to strengthen international solidarity.

Being one of the fundamental concepts of modern political science, the modern image of Russia and Russian national identity have been extensively studied in philosophy, sociology, social psychology, cultural and communication studies, political and cognitive linguistics, psycholinguistics and related fields. The studies in these fields seem to agree on the powerful potential of figurative language, and metaphor in particular, for the formulation of national ideology and activation of positive emotional states of society, which "feed" the feeling of patriotism within the country and encourage deference from foreign countries.
Despite the fact that studies into various aspects of the conceptual metaphor convincingly attest the crucial role of framing in the formation of socio-political views and beliefs, current research still lacks evidence of the efficiency of metaphorical framing as applied to constructing the positive image of Russia focusing on various target audiences and characterized by a certain degree of ideological profuseness. This study is an attempt to close this gap by determining the potential of figurative framing to form public opinion, ideologemes and beliefs in various value systems in regard to the image of Russia in domestic Russian and international public discourse. Methodologically, the paper integrates the theory of framing, the conceptual metaphor theory (CMT) and critical discourse analysis, and postulates the critical role of metaphor as a special type of framing - figurative framing - in the formation of beliefs and judgments about the image of modern Russia. This approach, in our opinion, proposes a new look at the structure of the frame and can be complementary to the theory of framing in general.

\section{Persuasive power of metaphor}

It was as early as antiquity when the strong persuasive power of figurative language means, and specifically metaphor, was first discovered. Early classical treatises treated figurative language as a rhetoric "decoration" which added more liveliness and emotional appeal to texts or speeches. From this viewpoint, it stood out as a considerable deviation from the standard language, which normally lacked any imagery. Metaphor, therefore, was a mere stylistic device and, consequently, did not implicate any conceptual content. Modern communication theory, on the contrary, emphasizes that metaphorical expressions frequently serve as a "condensing symbol" [Gamson, Modigliani 1989, 3]. This implies that they are able to concisely but vividly communicate a stance of 
certain politicians or interest groups. Accordingly, metaphor, from this perspective, serves as a framing tool functioning at the language level and referring to the possible ways something can be said rather than to what is said [Burgers, Konijn, Steen 2016]. A large body of foreign political science research has increasingly argued in favour of the ability of metaphor to function as a means which enhances formulating of ideologies by evoking people's emotions [Kitis, Milapides 1997; Lee 2005]. A similar line of research proposes that the degrees to which people from different cultural backgrounds exchange cultural knowledge and ideologies differ considerably [Charteris-Black, Musolff 2003; Charteris-Black 2004; Littlemore 2003; Trompenaars et al. 1993].

Applying certain patterns of metaphorizing socio-political processes can serve as a powerful technique of affecting public opinion. Such patterns may "prompt" the recipient of information which properties of the object they should focus on in order to be able to make sense of more complex abstract phenomena (target domain) in terms of more familiar and concrete (source domain) ones. Deliberate metaphorization inevitably contributes to the emergence and consolidation of particular stereotypes both within and outside a country and communicates a dominant ideology. The recent empirical evidence suggests the ability of metaphors to create the so-called metaphorical memes or "cultural constructs-replicators, transmitted from individual to individual through imitation" [Golubeva 2016].

From the standpoint of cognitive science and linguistics, a metaphor is a cross-domain mapping from a source to a target domain, the mechanism of which was first described in the 1980s by G. Lakoff and M. Johnson in their conceptual metaphor theory (CMT) [Lakoff, Johnson 2003]. Subsequently, the embodied nature of human language postulated by CMT became the basis for the neural theory of language and metaphor, which considers metaphor as a special type of neural connection [Feldman 2008]. Psycholinguistic studies have found that, for a cross-domain mapping from one domain to another to be possible, the source and the target domains are expected to be conceptually distant from each other, which enables to qualify as a metaphor. Therefore, to ensure that a metaphor is relevant and understandable to a target recipient, cross-domain similarity should be reduced to a minimum. The opposite is true about the intradomain similarity of both domains which should be as strong as possible [Gibbs (ed.) 2008]. It is only through meeting of these requirements that the "success" of metaphor as a framing tool can be ensured. The results obtained in previous research suggest that metaphor can be a powerful tool for affecting the audience [Sopory, Dillard 2002] which repeatedly counts in favour of power of metaphorical persuasion in political and public communication.

\section{Overview of framing research}

Over the past decade, scholars from various research fields have pointed to the pivotal role of framing in shaping stereotypes, political attitudes and beliefs. Framing has long become a key concept in understanding how media content affects its recipients [Golubeva 2016; Borah 2011; Lecheler, de Vreese 2012; Scheufele 1999]. The most common definitions of framing include the following:

- a denotative and semantic structure of a typical social situation, social subject or artifact [Minsky 1974, 31];

- a set of organizing principles shared by members of society [Reese et al. (eds.) 2001, 11];

- an explanatory scheme that simplifies and concisely expresses the external world through selective emphasis and coding of elements such as an object and a subject [Benford, Snow 2000];

- a specific set of interpretation schemes that serve to detect and understand information, as well as identify and categorize events and information [Goffman 1974, 584];

- the media's selection of certain aspects of an issue in order to raise their rank to highlight a particular cause of a phenomenon [Iyengar 1991, 11];

- sorting, exaggerating or diminishing the elements of the depicted reality to increase or decrease their "bulge" against the general information background [Entman 1991, 9];

- strategy for constructing and processing news discourse [Pan, Kosicki 1993, 57];

- creating a certain scheme for coding reality [Chong, Druckman 2007, 10]. 
In cognitive linguistics line of research, a frame is mainly understood either as a knowledge structure or a knowledge representation structure. Accordingly, a frame is defined either as "a structured fragment of knowledge of the world in some of its parts, formed in consciousness around some entity as a generalized idea of the sphere of its existence" [Nikitin 2004, 53], or as "a cognitive model that transfers knowledge and opinions about a certain, often recurring situation" [Boldyrev 2004, 18].

In studies of the effects of metaphorical framing on the formation of stereotypes and political beliefs, two approaches can be distinguished: critical discourse analysis (CDA) and elicited reactions analysis (ERA). The former one, aimed at determining the effects of metaphorical framing, analyzes real world changes as a result of such framing and the use of certain systematic language models [CharterisBlack, Mussolf 2003]. Thus, researchers do not create any predetermined situation, but attend mainly to the relations between naturally occurring discourse and the phenomena (events) of real life. Proponents of the second approach [Hartman 2012; Robins, Mayer 2000] examine the implications of metaphorical framing of political issues by exposing participants to specific language stimuli. In their opinion, one should focus on the ways of processing metaphors and their effects on the recipients, while controlling other factors. In doing so, it is important to show the causal effects of metaphorical framing. Proponents of these approaches are extremely critical of each other's research procedures and methods, questioning the validity and reliability of the results obtained [Boeynaems et al. 2017].

\section{Framing as a technology of media manipulation}

By manipulating the framework of text perception, journalists nowadays have gained the opportunity to considerably alter the semantic boundaries of a message, changing the options for its interpretation depending on a developing context. This is how the framing effect appears in the media, which is increasingly applied to enhance the impact on the audience in order to form a general public opinion. The concept of a frame is referred to by numerous scholars (G. Bateson, M. Minsky, J. Bruner, I. Hoffman) and is generally associated with a certain perception of reality and creating an orderly, consistent image of what is accepted and learned. As a rule, an audience is not aware of the frame, but any attempt of identifying and explaining it results in distortion of perception and activities. Just as our personal narratives give rise to individual words and phrases in our speech, so do frames in defining our reality on the perceptional, emotional and cognitive levels. This, in its turn, contributes to more simplified (but not necessarily adequate) understanding of a situation and developing your own attitude towards it for subsequent actions. Similarly, the media act at the level of stereotypes, collecting numerous fragments of empirical reality and constructing a consistent image of an event that meets the views of mass media actors and audience's demands.

Being affected by a piece of information presented from a particular perspective, the audience acquires a certain image, with a preference given in favor of one or another solution. The way of presenting information is referred to as framing since it foregrounds some positive aspects of an event by overshadowing negative ones. The type of framing the media resorts to has a critical impact on people's judgments and beliefs, and, therefore, is a powerful factor affecting their behaviors. It is exactly in this way that framing is applied in news media coverage, political speeches, propaganda and advertising. Meanwhile, some researchers note that "when people are exposed to many conflicting (contested) frames, the framing effect is neutralized, and people think and act in accordance with their own beliefs "[Lidwell, Holden, Butler 2003, 108-109].

N. Ponomarev significantly expands the concept of framing and treats it not as a separate type of manipulative technology, but as a strategic tool for constructing communication in various spheres of social life. Depending on the object and purpose, he identifies five types of framing:

- interactive framing - constructing certain models of a situation by its participants for better understanding and coordinating actions;

- motivational framing - encouraging group members by their leaders to take concerted collective actions through coordinating their values and goals;

- problem framing - detecting, assessing, explaining the reasons, forecasting the 
consequences and prescribing actions that an actor takes in relation to a specific issue in question;

- media framing - constructing and promoting advocating stories into the media sphere aimed at affecting the composition and quality of problem issues, as well as media content in general;

- news framing - journalists' creating and applying of media frames which have been clearly established ideas about the pressing disputable issues [Ponomarev 2013, 17].

The classification above gives rise to five corresponding types of techniques applied in various combinations in media: metaphorization (metaphoric framing), visualization (visual rhetoric), schematization (scenario framing), narrativation (narrative framing), recreation (fictional framing) [Sarna 2020, 230]. When used in combinations, these techniques appear to be strikingly effective in affecting people's views of disputable societal issues. For instance, framing and story-telling are closely interrelated, as the former is one of the tools for narrativation, understood as an interpretation of social phenomena in the format of a story. Thus, the power of framing is dependent both on the cohesion (unambiguity of a plot) and validity (meeting audience's values). The latter is helpful in detecting and matching various frames when creating stories related to a particular social phenomenon.

The current paper argues that, given the multimodal nature of metaphor, its imageschematic organization and pervasiveness of metaphorical reasoning across various types of discourse, figurative (metaphoric) framing comprises all the aforementioned types of framing. When used in clusters, metaphors that co-occur in the public and media discourse give rise to a holistic extended metaphorical narrative foregrounding a particular view of the Russian identity. This approach substantiates the idea that one of the functions of metaphor in discourse is to legitimize policies "through providing access to the system of underlying social and cultural values" [Skrynnikova, Astafurova 2020].

\section{Metaphorical framing as a tool of constructing the image of Russia}

An established positive image is one of the constants that determine the content of socio- cultural communication in modern Russia. Being conditioned by worldview pluralism, forms of image representation in different ideological political and historical contexts acquire new cultural implications in society. However, they still encounter serious challenges and contradictions, primarily due to the discrepancy between the positive statements of the country and the objective reality. The positive image of Russia as a communicative and cognitive processual phenomenon is conveyed through thematically expressed semiotic forms in the unity of their linguistic, mental and subject aspects.

Constructing a country's positive image primarily means affecting the perception and emotional states of different target audiences and, therefore, performs the cognitive, evaluative and informative-communicative functions. The former function of the positive image of Russia appears to be one of the relevant ones for the current research due to the fact that language and a myriad of linguistic means form, express, disseminate, support and express the content of the culture. This function involves not only forming and disseminating certain knowledge in a certain cultural space, but rather ensuring conditions for the emergence of this knowledge.

A positive image of Russia is being actively promoted in modern mass media culture (TV, popular journalism, political and travel blogs) through verbal and visual means and ready-made discursive formulas. The main "units" of the national patriotic mobilization discourse are Russia, Motherland, Fatherland, people, nation, patriotism, unity, enemy, terrorism, war, defense, army, heroism, and victory. Intensive exchange or reconfiguration of the language, familiar to a layman and reducible to simplified and understandable clichés supports active generating of new forms. This is where metaphorical frames are employed to interprete abstract and otherwise ambiguous or contested concepts related to the country.

The public and media discourse about modern Russia aimed at patriotization of the Russian youth, as our literature review suggests [Ryabov, Ryabova 2016; Martynova 2011; Koteyko, Ryazanova-Clarke 2009; Budaev, Chudinov 2006; Charteris-Black 2005; Wodak, De Cillia, Reisigl 1999; Bourmeyster 1998; Neumann 1998] relies mainly on the building / 
construction, mother and bear as well as journey / path metaphors. The first two are commonly found in the public speeches delivered by President Putin and party leaders. They are effective in framing and provide some evaluation of contested topics [Musolff 2004] along with legitimizing political initiatives.

The path metaphor, continuingly resorted to since the Soviet era, combines with the building metaphor and transforms to frame the discourse of perestroika dominated by the journey / road and construction / building metaphors. The use of the path metaphor in the post-perestroika era was clearly pervasive reflecting the pressing need for elaborating a common political language and an ideology aimed at replacing the Communist views. In more recent years, this search for a unique path has been initiated by President Vladimir Putin through applying discursive mechanisms of constructing a patriotism-based Russian national identity communicated with path and building metaphors.

Employing the maternal image of Russia is exercised through both linguistic and visual metaphoric representations of Russianness. It is worth mentioning that the mother metaphor has been strikingly powerful both within the country and abroad, although with an ironical colouring the Western media demonstrates. Referring to Russia as Mother is, on the one hand, pervasive in constructing the Russian national identity, and, on the other hand, emphasizes how different Russia is from alien and frequently hostile "others". The idea of Russian opposition to the West has been heavily exploited throughout centuries, which could hardly serve to the advantage of Russia in terms improving its international image.

The Russia is a Bear metaphor pervades the discourse of stereotyping about Russia and its people. From the Western perspective, a bear metaphor marks a symbolic border with Russia emphasizing its non-European essence and values, aggressive character and awkwardness. The foreign view of the Russian bear in international relations cannot but evoke negative evaluations of the bear, of the ongoing clashes between Russia and the West. Resorting to the bear metaphor within the counrty emphasizes the dissimilarity of Russia in its opposition to the rest of the world. The bear symbolizes the master of "the Russian forest" prompting the idea of responsibility for both the country borders and foreign and domestic policy. The bear metaphor in foreign mass media is increasingly found in semiotic systems different from language (visual, gestural, etc.) [Wodak, De Cillia, Reisigl 1999, 153] (e.g. caricatures and demotivators). It is pervasively referred to not only by journalists, but also expert communities and politicians, i.e. those who are in charge of foreign policy decisions.

Foreign policy rhetoric and national identity discourse is ripe with the bear metaphor which suggests its high salience and value and results in corresponding inferences about the country and its citizens.

Clusters of multimodal metaphors forming the extended metaphorical narrative of Russia are effective tools of communicating and promoting a positive view of the country which is to an advantage of certain political actors. In this respect, metaphorical framing the country and its policies in a particular way meets the needs arising in an ever changing social and political climate [Skrynnikova, Astafurova, Sytina 2017]. Therefore, the critical role of metaphor framing at the level of conceptual processing mechanisms and meaning making is hardly disputable. Figurative framing and metaphor are now seen as part and parcel of constructing and communicating a positive view of the country.

\section{Conclusion}

The presented research seems to provide some evidence in favor of applying figurative framing as a promising method of constructing a positive image of Russia. Selecting the "right" frames by public actors and mass media may result in the improved view of Russia and its priorities, contribute to identifying some vision, causes, assessment and solutions to significant social and political problems. In other words, researchers studying framing should be more careful and selective in terms of focusing on particular frames, the relevance and implications of applying them for improving the country's image. Such an approach should be exercised not only in the political arena but also in terms of attracting foreign capital and tourists and raising patriotic feelings among the Russian youth. The decision to resort to a particular frame depends 
on a covered topic (a type of problem), an ideology of a public actor, as well as on the characteristics / properties foregrounded by reputable sources and the media.

The value of the proposed method for improving the image of Russia lies in the fact that figurative frames can provide a target audience with a special perspective on the problem in question, pushing them to choose a "right" solution to the problem which serves to an advantage of socio-political actors. This suggests that such frames can be commonly employed to an audience with low awareness of a particular issue. Therefore, we believe that, in view of their explanatory power, figurative frames pervade the discussions of relatively new topics to a greater extent (for example, changes to the Internet regulatory policy such as net neutrality, COVID vaccination passports, etc.) than the ones formerly known to the recipient. Moreover, abstract and intricate topics, incomprehensible to grass roots, call for the use of metaphorical frames more regularly than concrete, traditional political topics to facilitate their understanding.

Metaphorical frames in social and political communication can be used to displace competing frames and activate the existing ones, as well as to reframe political and social events that have become unpopular among the citizens. An illustrative example in this regard is the statement of the former Russian Minister of Education Olga Vasilyeva on the need to abandon the interpretation of the forprofit education in Russia as educational services. This understanding is based on the metaphor EDUCATION is A SERVICE, which inevitably entails an appropriate distribution of the participants' roles in the educational process. Within the framework of this model, students are customers (clients), while lecturers and professors are maintenance staff who provides the service. Since the customer is always right, the service should be provided (a test or an exam passed) regardless of whether the customer of the service (student) fulfilled the obligations to its performer (lecturer) in the form of covered material on the subject and a certain number of tasks. This approach not only results in a devaluation of the teaching profession, decreased motivation in students, but generally negatively affects the quality of education and the proficiency of current students. As a result, the demand for such specialists in the labor market and the competitiveness of Russian education in the international arena slump.

Figurative framing is specifically effective in the context of debates on controversial and contested issues. In such a debate, both opponents seeking to challenge existing frames and proponents who advocate preserving them activate competing metaphorical frames leading the audience to make the inherent inferences. Conversations can also apply opponents' frames to their disadvantage without activating the competing ones. Such tactics has greatly assisted the US President Donald Trump in his election campaign and resulted in his winning the campaign.

The next key point in figurative framing is the "styling" of the frame. This process lies in the fact whether the generated frames are passed on to and activated in the audience, and if so, when and what implications it may have on the audience. The salience of a frame is considered high if the audience applies it while reasoning about the target concept. The use of figurative frames, in our opinion, can significantly increase their salience against other frames in the context of discussing a particular problem. We assume that they are more memorable compared to literal frames due to their ability to make sense about a complex topic, thus, raising awareness of an issue or introducing a creative way of thinking about a topic.

The major finding of the study is revealing the ways in which figurative framing and discourse metaphors can be applicable to improving the image of Russia. The power of metaphor as a framing tool is high due to its possessing both linguistic and conceptual content. The poor repertoire of metaphoric frames currently applied in the public and media discourse suggests that a positive image of Russia can be attained through expanding the range of metaphorical frames and selecting the ones which would contribute to its greater global recognition and reputation. One of the possible directions for reframing the Russian stance could be rejecting the excessively militarized discourse around the country and focusing on its cultural heritage, academic achievements and openness to enhanced international interaction. Employing positively charged metaphorical national narrative, reframed to draw particular attention to the merits and gains 
of Russia enables to significantly increase its transformative and manipulative effect in the discursive construction of the Russian image within and outside the country.

The findings of the study may be applied as recommendations and guidelines for further research into framing effects and critical metaphor discourse, political science and media studies as well as for training professionals in the related fields.

\section{NOTE}

${ }^{1}$ The article was prepared with the support of the Russian Foundation for Basic Research, project no. 20-011-31715 "Strategies of constructing the image of Russia through figurative framing".

\section{REFERENCES}

Boldyrev N.N., 2004. Conceptual Space of Cognitive Linguistcs. Voprosy kognitivnoj lingvistiki, no. 1,pp. 18-36.

Budaev E.V., Chudinov A.P., 2006. Metaphor in Political Interdiscourse. Monograph. Yekaterinburg, Ural state pedagogical university.

Golubeva T.M., 2016. Metaphor as a Language Means of Creating and Actualizing Public Ideologies. Vestnik Nizhegorodskogo universiteta im. N.I. Lobachevskogo, Philology, vol. 2, no. 2, pp. 212-216.

Lidwell W., Holden K., Butler J., 2003. Universal Principles of Design. Saint Peterburg, Piter Publ.

Martynova Yu.A., 2011. Metaphorical Basis of Modern Russian Patriotic Discourse. Izvestiya Saratovskogo universiteta. Novaya seriya. Seriya Sociologiya. Politologiya, vol. 11, no. 1, pp. 293-297.

Nikitin M.V., 2004. Detailed Theses About Concepts. Voprosy kognitivnoj lingvistiki, no. 1. pp. 53-64.

Ponomarev N.F., 2013. Media Framing as a Key Discursive Strategy. Vlast', no. 9, pp. 93-97.

Ryabov O.V., Ryabova, T.B., 2016. The Symbol of the Motherland as a Resource for the Formation of Russian Civil Identity. Chelovek. Soobshchestvo. Upravlenie, vol. 17, no. 2, pp. 99-114.

Sarna A.Ya., 2020. Technologies of Affecting the Audience in the Modern Media Space. Vestnik Sankt-Peterburgskogo universiteta. Sociology, vol. 13 (2), pp. 218-235. DOI: https://doi.org/ 10.21638/spbu12.2020.207.

Benford R.D., Snow D.A., 2000. Frame Processes and Social Movements: an Overview and Assessment. Annual Review of Sociology, vol. 26, pp. 611-639.
Bourmeyster A., 1998. The Restructuring of Soviet Political Discourse. Political Discourse in Transition in Europe 1989-1991. Chilton P., Ilyin M., Mey J. (eds.). Amsterdam, John Benjamin's Publishing Company, pp. 69-87.

Boeynaems A., Burgers C. F., Konijn E. A., Steen G. J., 2017. The Effects of Metaphorical Framing on Political Persuasion: A Systematic Literature Review. Metaphor and Symbol, no. 32 (2), pp. 118-134.

Borah P., 2011. Conceptual Issues in Framing Theory: A Systematic Examination of a Decade's Literature. Journal of Communication, vol. 61, iss. 2, pp. 246-263.

Burgers C.F., Konijn E.A., Steen G. J., 2016. Figurative Framing: Shaping Public Discourse Through Metaphor, Hyperbole, and Irony. Communication Theory, vol. 26, iss. 4, pp. 410-430.

Charteris-Black J., 2005. Politicians and Rhetoric. The Persuasive Power of Metaphor. Basingstoke, New York, Palgrave-MacMillan.

Charteris-Black J., 2004. Critical Analysis of Metaphors. Corpus Approaches to Critical Metaphor Analysis. London, Palgrave Macmillan.

Charteris-Black J., Musolff A., 2003. 'Battered Hero' or 'Innocent Victim'? A Comparative Study of Metaphors for Euro Trading in British and German Financial Reporting. English for Specific Purposes, no. 22 (2), pp. 153-176. DOI: https:// doi.org/10.1016/S0889-4906(02)00012-1.

Chong D., Druckman J.N., 2007. A Theory of Framing and Opinion Formation in Competitive Elite Environments. Journal of Communication, no. 1, pp. 99-118.

Entman R.M., 1991. Framing U.S. Coverage of International News: Contrasts in Narratives of the KAL and Iran Air Incidents. Journal of Communication, no. 41 (4), pp. 6-27.

Feldman J.A., 2008. From Molecule to Metaphor. A Neural Theory of Language. Cambridge, MIT Press.

Gamson W.A., Modigliani A., 1989. Media Discourse and Public Opinion on Nuclear Power: A Constructionist Approach. American Journal of Sociology, no. 95 (1), pp. 1-37. DOI: https:// doi.org/10.1086/229213.

Gibbs R.W.Jr. (ed.), 2008. The Cambridge Handbook of Metaphor and Thought. Cambridge, Cambridge University Press.

Goffman E., 1974. Frame Analysis: An Essay on the Organization of Experience. Cambridge, Harvard University Press.

Hartman T.K., 2012. Toll Booths on the Information Superhighway? Policy Metaphors in the Case of Net Neutrality. Political Communication, no. 29 (3), pp. 278-298. DOI: https://doi.org/ 10.1080/10584609.2012.694983. 
Iyengar S., 1991. Is Anyone Responsible? How Television Frames Political Issues. Chicago, University of Chicago Press.

Kitis E., Milapides M., 1997. Read it and Believe it: How Metaphor Constructs Ideology in News Discourse. A Case Study. Journal of Pragmatics, no. 28 (5), pp. 557-590.

Koteyko N., Ryazanova-Clarke L., 2009. The Path and Building Metaphors in the Speeches of Vladimir Putin: Back to the Future? Slavonica, vol. 15, p. 112-127.

LakoffG., Johnson M., 1980/2003. Metaphors We Live by. Chicago, The University of Chicago Press.

Lecheler S., de Vreese C.H., 2012. News Framing and Public Opinion. Journalism \& Mass Communication Quarterly, vol. 89, iss. 2, pp. 185-204.

Lee D.A., 2005. The Perfect Nurturer: A Model to Develop a Compassionate Mind Within the Context of Cognitive Therapy. P. Gilbert (ed.). Compassion: Conceptualizations, Research and Use in Psychothrapy. London, Routledge, pp. 326-351.

Littlemore J., 2003. The Effect of Cultural Background on Metaphor Interpretation. Metaphor and symbol, no. 18 (4), pp. 273-288.

Minsky M., 1974. A Framework for Representing Knowledge. Cambridge.

MusolffA., 2004. Metaphor and Political Discourse: Analogical Reasoning in Debates About Europe. London, Palgrave Macmillan.

Neumann I.B., 1998. Constructing Europe: Russia as Europe's Other. Hedetoft U. (ed.). Political Symbols, Symbolic Politics: European Identities in Transformation. Aldershot; Brookfield, Ashgate.

Pan Z.D., Kosicki G.M., 1993. Framing Analysis: An Approach to News Discourse. Political Communication, no. (10), pp. 55-75.
Reese S.D. et al. (eds.), 2001. Framing Public Life: Perspectives on Media and Our Understanding of the Social World. Mahwah, Lawrence Erlbaum Associates.

Robins S., Mayer R.E., 2000. The Metaphor Framing Effect: Metaphorical Reasoning About TextBased Dilemmas. Discourse Processes, no. 30 (1), pp. 57-86. DOI: https://doi.org/10.1207/ S15326950dp3001 03.

Scheufele D.A., 1999. Framing as a Theory of Media Effects. Journal of Communication, no. 49 (1), pp. 103-122. DOI: https://doi.org/10.1093/joc/ 49.1.103.

Skrynnikova I.V., Astafurova T.N., 2020. Constructing Modern Russian Identity Through Discourse Metaphors. Vestnik Volgogradskogo gosudarstvennogo universiteta. Seriya 2. Yazykoznanie, vol. 19, no. 3, pp. 107-115. DOI: https://doi.org/10.15688/jvolsu2.2020.3.10.

Skrynnikova I.V., Astafurova T.N., Sytina N.A., 2017. Power of Metaphor: Cultural Narratives in Political Persuasion. Current Issues of Linguistics and Didactics: The Interdisciplinary Approach in Humanities. Proceedings of the $7^{\text {th }}$ International Scientific and Practical Conference (Atlantic Press), pp. 285-290.

Sopory P., Dillard, J.P., 2002. The Persuasive Effects of Metaphor: A Meta-Analysis. Human Communication Research, no. 28(3), pp. 382-419.

Trompenaars A., Hampden-Turner Ch., 1993. The Seven Cultures of Capitalism: Value Systems for Creating wealth in the United States, Japan, Germany, France, Britain, Sweden, and the Netherlands. New York, Doubleday Business. $405 \mathrm{p}$.

Wodak R., De Cillia R., Reisigl M., 1999. The Discursive Construction of National Identity. Discourse and Society, vol. 10, no. 2, pp. 149-173.

\section{Information About the Author}

Inna V. Skrynnikova, Candidate of Sciences (Philology), Associate Professor, Germanic and Romance Philology Department, Volgograd State University, Prosp. Universitetsky, 100, 400062 Volgograd, Russian Federation, i.skrynnikova@volsu.ru, https://orcid.org/0000-0002-2390-7866

\section{Информация об авторах}

Инна Валериевна Скрынникова, кандидат филологических наук, доцент кафедры германской и романской филологии, Волгоградский государственный университет, просп. Университетский, 100, 400062 г. Волгоград, Российская Федерация, i.skrynnikova@volsu.ru, https://orcid.org/0000-0002-2390-7866 